\title{
Analysis of morphometric traits in heterogeneous population of adult guinea fowl
}

\section{(Numida meleagris)}

Dudusola, I. O., Bashiru, H. A. and Adewuyi, A. A.

Department of Animal Sciences, Obafemi Awolowo University, 220005, Nigeria

*Corresponding author: dipodudu2000@yahoo.com; +2348034069743

Abstract

Guinea fowls represent an important animal genetic resource for food security in Nigeria. This study was conducted to investigate sexual dimorphism and the effect of location on morphometric traits in guinea fowls, obtain fewer uncorrelated orthogonal variables (principal components) from body linear measurements of guinea fowl, obtain homogeneous groups from a heterogeneous set of adult guinea fowl and predict live body weight of guinea fowls using body linear measurements of guinea fowl. A total of one thousand and seventeen $(1,017)$ adult guinea fowl varieties aged between 28 and 39 weeks $(774$ pearls; 64 lavenders; 151 black and 28 white varieties) consisting of 457 males and 560 females were randomly selected from rural farmers and markets in two Local Government Areas (LGAs) each in Osun and Oyo States in South-Western Nigeria. Data were collected on body weight, helmet height, wattle length, thigh length, body circumference, shank length, body length, neck length, wing length using standard procedures. Data collected were analyzed using GLM, REG, PRINCOMP and CLUSTER procedures of SAS. There were significant differences $(p<0.05)$ in all morphometric traits except thigh length and wingspan among the four varieties. The location did not have a significant effect $(p>0.05)$ on the morphometric traits of guinea fowl. However, guinea fowls were found to be sexually dimorphic for body weight and all morphometric traits. Three principal components were yielded for the pearl, black and white variety which explained $60 \%, 75 \%$, and $85 \%$ of the generalized variances respectively for the three varieties. Two principal components were yielded by the factor solution in the case of lavender variety which explained $68 \%$ of the total variances. The thigh length, body circumference, and wattle length contribute to the total variability of PC1 and these traits could be used for selection in the breeding programme to improve the body weight of the genetics stocks guinea fowl. The significant and positive associations indicated by the prediction equations between body weight and body linear parameters showed that the regression equations could be used to predict body weight.

Keywords: Morphometric traits; principal components; clusters; sexual dimorphism

\section{L'Analyse des caractères morphométriques dans la population hétérogène de pintade adulte (Numidameleagris)}

\section{Résumé}

Les pintades représentent une ressource génétique importante pour la sécurité alimentaire au Nigéria. Cette étude a été menée pour étudier le dimorphisme sexuel et l'effet de l'emplacement sur les caractères morphométriques chez les pintades, obtenir moins de variables orthogonales non corrélées (principaux composants) à partir de mesures linéaires corporelles de la pintade, obtenir des groupes homogènes à partir d'un ensemble hétérogène de pintades adultes et prédire le poids corporel vivant des pintades à l'aide de mesures linéaires corporelles de la pintade. Un total de mille dix-sept (1 017) variétés de pintades adultes âgées de 28 à 39 semaines (774 perles; 64 lavandes; 151 variétés noires et 28 variétés blanches) composées de 457 mâles et 560 femelles ont été choisies au hasard parmi les 


\section{Morphometric traits of adult guinea fowl}

agriculteurs ruraux et les marchés de deux zones d'administrations locales (les 'LGA) chacune dans les États d'Osun et d'Oyo, dans le sud-ouest du Nigeria. Des données ont été recueillies sur le poids corporel, la hauteur du casque, la longueur du wattle, la longueur des cuisses, la circonférence du corps, la longueur de la tige, la longueur du corps, la longueur du cou, la longueur des ailes à l'aide de procédures standard. Les données recueillies ont été analysées à l'aide des procédures 'GLM', 'REG', 'PRINCOMP' et 'CLUSTER' de 'SAS'. Il y avait des différences significatives $(p<0,05)$ dans tous les traits morphométriques, à l'exception de la longueur et de l'envergure des cuisses entre les quatre variétés. L'emplacement n'a pas eu d'effet significatif $(p>0,05)$ sur les traits morphométriques de la pintade. Cependant, les pintades se sont trouvées sexuellement dimorphic pour le poids corporel et tous les traits morphométriques. Trois composants principaux ont été cédés pour la variété de perle, noir et blanc qui a expliqué $60 \%, 75 \%$, et $85 \%$ des écarts généralisées respectivement pour les trois variétés. Deux composants principaux ont été rapportés par la solution de facteur dans le cas de la variété de lavande qui a expliqué $68 \%$ des écarts totaux. La longueur des cuisses, la circonférence du corps et la longueur du wattle contribuent à la variabilité totale du PCl et ces traits pourraient être utilisés pour la sélection dans le programme de reproduction afin d'améliorer le poids corporel des stocks génétiques de pintades. Les associations significatives et positives indiquées par les équations de prédiction entre le poids corporel et les paramètres linéaires du corps ont montré que les équations de régression pouvaient être utilisées pour prédire le poids corporel.

Mots-clés: Traits morphométriques; principaux composants; grappes; dimorphisme sexuel

\section{Introduction}

Guinea fowls represent an important genetic resource in Nigeria. According to Ikani and Dafwang (2004), they make up about $25 \%$ of the overall poultry population in the country and they are over 50 million in number. Thus, they are next only to chickens in terms of population and value. A key factor to their popularity in the country, especially among smallholder poultry farmers, is the discovery that they are more resistant to most diseases of chickens with a higher capacity to scavenge for grains and insects (Microlivestock, 1991). Thus, they are a veritable source of animal protein without taboos and a valuable genetic resource for smallholder farmers (Ikani and Dafwang, 2004). Further, they can be successfully reared with minimal effort in the farms or around villages. According to Mareko et al. (2006), its production is gaining ground worldwide, notably in developing countries with rising demand for its meat due to the added advantage of its gamy flavor. Despite their great production potentials in Nigeria, the production of guinea fowl remains at a subsistent, semidomesticated, and backyard level in the country, with low input levels resulting in low profitability (Fajemilehin and Salako, 2017). A key impediment is the limited scientific information on their growth performance and morphological indices. Another factor is the fact that this vital genetic resource remains largely unimproved. For this bird to be relevant in large scale production, its performance characteristics should be improved. Genetic improvement programmes depend on access to morphological and genetic variations. Morphometric traits are quantitative traits that describe the shape and forms of an animal. These include shank length, wing length, wattle length, body circumference, helmet height, and thigh length. According to Dossa et al. (2007), morphometric traits are highly correlated. Therefore, estimation of breeding values based on them is unreliable and thus make it difficult to incorporate 


\section{Dudusola, Bashiru and Adewuyi}

them in genetic improvement programmes. Univariate statistical analytical techniques such as analysis of variance (ANOVA) are aimed at measuring individual variables and do not specify how the population differs when considering all measured parameters together (Dossa et al., 2007). Multivariate statistics are however statistical methods that can simultaneously analyze multiple variables. Therefore, multivariate techniques such as principal component analysis and cluster analysis have been suggested to analyze multiple variables simultaneously (Yakubu and Ibrahim, 2011). Cluster analyses are useful in determining heterogeneity within a population (Traoré et al., 2008) while principal component analysis can be utilized to transform multiple correlated variables into uncorrelated variables (Johnson and Wichern, 2007). Therefore, the objectives of this study were to investigate sexual dimorphism and the effect of location on morphometric traits in guinea fowls, obtain fewer uncorrelated orthogonal variables (principal components) from body linear measurements of guinea fowl, obtain homogeneous groups from a heterogeneous set of adult guinea fowl and predict live body weight of guinea fowls using body linear measurements of guinea fowl.

\section{Materials and methods \\ Experimental locations}

This study was conducted in Oyo and Osun States of Nigeria. The two states are located in the Southwestern part of the country and fall within the Guinea Savanna zone. Two Local Government Areas (LGAs) each in Osun (Osogbo and Ejigbo LGA) and Oyo (Ogbomoso and Saki-West LGA) States were purposely selected due to the presence of a high population of guinea fowls. Oyo state lies within the coordinates of latitude $8.1196^{\circ} \mathrm{N}$, longitude $3.4196^{\circ} \mathrm{E}$, Osun state lies within latitude $7.5876^{\circ} \mathrm{N}$, longitude $4.5624^{\circ} \mathrm{E}$, Saki lies within latitude $8.6726^{\circ} \mathrm{N}$, longitude $3.3943^{\circ} \mathrm{E}$, Ogbomoso lies within latitude $8.1227^{\circ} \mathrm{N}$, longitude $4.2436^{\circ} \mathrm{E}$, Osogbo lies within latitude $7.7827^{\circ} \mathrm{N}$, longitude $4.5418^{\circ} \mathrm{E}$ and Ejigbo lies within latitude $7.9045^{\circ} \mathrm{N}$, longitude $4.5418^{\circ} \mathrm{E}$, (Fajuyigbe et al., 2007).

\section{Experimental birds and management}

Guinea fowls used in this study were owned by smallholder farmers that rear them extensively. They were allowed to scavenge freely and were supplied with little or no supplementary feeding. Only female adult guinea fowls that have started laying and adult males judged by the size of their helmet were used to ensuring that only mature birds were used. Data were obtained only from seemingly healthy birds.

\section{Data collection}

A sample of one thousand and seventeen $(1,017)$ adult guinea fowls comprising of seven hundred and seventy-four (774) pearl, one hundred and fifty-one (151) black, sixty-four (64) lavender and twentyeight (28) white varieties were used for the study. Data collected were body weight and nine morphometric traits on each of the birds. The morphometric variables recorded were neck length, body length, body circumference, shank length, wingspan, thigh length, wing length, helmet height, and wattle length. The body weight of individual bird was taken using KERRO electronic compact scale (model number BL50001) with a maximum capacity of $5000 \mathrm{~g}$ and sensitivity of $0.1 \mathrm{~g}$. The length and circumference were measured in centimetres $(\mathrm{cm})$ using a graduated measuring tape. All linear body measurements were measured by one person to minimize measurement errors due to individual differences and body linear parameters were taken in the morning before feeding following FAO (2012) to prevent unnecessary variations.

\section{Data analysis}

General Linear Model (GLM) procedure of 
$\operatorname{SAS}^{\circledR}$ (2002) was used to evaluate the effect of sex and location on the morphometric traits according to the following model;

$\mathrm{Y}_{\mathrm{ijk}}=\mu+\alpha_{\mathrm{i}}+\beta_{\mathrm{j}}+(\alpha \beta)_{\mathrm{ij}}+\mathrm{e}_{\mathrm{ijk}}$

$\mathrm{Y}_{\mathrm{ijk}}=\mathrm{k}^{\text {th }}$ observation ; body weight, shank

length etc

$\mu=$ overall mean;

$\alpha_{i}=$ fixed effect of $\operatorname{sex}(i=1,2)$;

$\beta \mathrm{j}=$ fixed effect of location $(\mathrm{j}=1,2,3,4)$;

$(\alpha \beta)_{i j}=$ interaction between $i^{\text {th }}$ sex and $j^{\text {th }}$ location

$\mathrm{e}_{\mathrm{ijk}}=$ Random error, assumed to be normally and independently distributed (Kaps and Lamberson, 2004).

REG procedure of SAS ${ }^{\circledR}$ (2002) was used to generate equations to predict live body weight from morphometric traits according to this equation:

$\mathrm{BW}=\mathrm{a}+\mathrm{b}_{1} \mathrm{x}_{1}+\mathrm{b}_{2} \mathrm{x}_{2}+--------\mathrm{b}_{\mathrm{n}} \mathrm{x}_{\mathrm{n}}+\mathrm{e}$

$\mathrm{BW}=$ Body weight

$\mathrm{a}=$ intercept

$\mathrm{b}_{1}, \mathrm{~b}_{2} \ldots \ldots \mathrm{b}_{\mathrm{n}}=$ Regression coefficient.

$\mathrm{x}_{1} \mathrm{X}_{2}, \ldots \ldots \mathrm{X}_{\mathrm{n}}=$ measured traits.

$\mathrm{e}=$ random error

Further, the data collected were analyzed using the PRINCOMP procedure of SAS ${ }^{\circledR}$ (2002) software to obtain fewer uncorrelated orthogonal variables from morphometric traits of adult guinea fowl. Cluster analysis was performed using PROC CLUSTER of the same software.

\section{Results and discussion}

Body weight and morphometric traits of the four varieties of guinea fowl

Table 1 shows the descriptive statistics of body weight and morphometric traits for the four varieties of guinea fowls sampled. There were significant differences $(\mathrm{p}<0.05)$ in body weight, shank length, body length, neck length, wing length, body circumference, wattle length, and helmet height among the four varieties. However, there were no significant differences $(p>0.05)$ between the thigh length and wingspan of the four varieties. The similarity observed in the thigh length, and wingspan of the four varieties suggests a similarity in the gene responsible for the thigh length and wingspan in these varieties. According to Ayorinde (2004), the similarity of body parameters among breeds or varieties might be due to similarity in the gene responsible for such parameters. The pearl variety was observed to be heavier than other varieties while the white variety was observed to be lightest. The significant differences in the body weight, as observed in this study, could be an indication of the inherent genetic variation among the varieties. The values of body weight obtained in this study were similar to the value of 1000 - $1500 \mathrm{~g}$ reported by Ayorinde (1999) for free ranging adult birds; $1175 \mathrm{~g}$ reported for unselected guinea fowls and $1406 \mathrm{~g}$ for local guinea fowls (Ayorinde and Oluyemi, 1991). However, it was lower when compared to $1800 \mathrm{~g}$ reported for exotic breeds and the crosses of the breed with indigenous varieties (Ayorinde and Oluyemi, 1991) and 1507g for Pollastra guinea fowl imported from Galor and Pollastra a cross of indigenous guinea fowl (Ayorinde, 1996). The variations in body weight could be as a result of differences in the genotype of the birds used (Culioli et al., 1990 and Leterrier et al., 1999), age of the birds (Mareko et al., 2008), diet composition (Chiericato et al., 2001; Frątczak et al., 2002), sex (Baéza et al., 2001 and Mareko et al.,2006), housing system (Mareko et al., 2006 and Mareko et al., 2008), management practices employed (Porwal et al., 2007) as well as differences in the climatic conditions of the environment (Pudyszak et al., 2005).

The shank length of the white variety was observed to be longest while the lavender variety had the least. The shank length of a range of $6.90-8.41 \mathrm{~cm}$ recorded in this study is higher than the shank length of $6.61 \mathrm{~cm}-7.32 \mathrm{~cm}$ reported by Fajemilehin, 


\section{Dudusola, Bashiru and Adewuyi}

(2014). The wing lengths of $20.54 \mathrm{~cm}$, $20.07 \mathrm{~cm}, 19.44 \mathrm{~cm}$ and $18.78 \mathrm{~cm}$ for pearl, black, lavender, and white varieties of guinea fowl respectively generated in this study are similar to the values of $20.04 \mathrm{~cm}$, $18.25 \mathrm{~cm}, 19.55 \mathrm{~cm}$, and $19.08 \mathrm{~cm}$ obtained by Fajemilehin (2014). The wattle length of $1.61-2.32 \mathrm{~cm}$ obtained was similar to 1.49 $-2.08 \mathrm{~cm}$ reported by Fajemilehin (2014). The helmet of the lavender variety was observed to be the longest. The values of helmet height which ranged from $2.09 \mathrm{~cm}$ to $2.27 \mathrm{~cm}$ were higher than the values reported for helmet height by Fajemilehin (2014) and are considerably lower than the value of $3.2 \mathrm{~cm}$ reported by Ayorinde (2004) for the same trait.

Body weight and morphometric traits of adult guinea fowl based on sex and across four locations

Table 2 shows the means and standard errors of body weight and morphometric traits of guinea fowls based on sex across the four locations (Saki, Ogbomosho, Ejigbo, and Osogbo). There were similarities in the body weight and all the body measurement across all the locations $(p>0.05)$ which indicated that location did not have a significant effect on all the traits considered. In contrast, sex had a significant effect $(p<0.05)$ on all the traits considered with the male showing higher values over the female for all the traits measured. This indicated that turkeys are sexually dimorphic for the studied traits. Baeza et al. (2001) observed significant variation between male and female ducks in a similar study. The authors attributed such differences to sexual dimorphism. Further, Deeb and Cahaner (2001) reported that sexual dimorphism could be due to differing effects of sex hormones on the growth and development process. This notion is further supported by Zaky and Amin (2007) who reported that sex hormones are mainly responsible for animals to be sexually dimorphic.

Prediction of body weight from morphometric traits measured

The significant association among body weight and body linear parameters indicated by the prediction equations showed that the regression equations could be useful in predicting body weight. The highest coefficient of determination $\left(R^{2}\right)$ is in the wattle length which had the highest accuracy to predict body weight compared to the other body linear measurements in pearl, black and lavender varieties while the wingspan had the highest coefficient of determination for the white variety.

Table 1: Body weight and different morphometric traits for the four varieties of Guinea fowl

\begin{tabular}{lllll}
\hline Traits & Pearl $(\mathbf{n}=\mathbf{7 7 4})$ & Black $(\mathbf{n = 1 5 1})$ & Lavender $(\mathbf{n}=\mathbf{6 4})$ & White $(\mathbf{n = 2 8})$ \\
\hline Body weight & $1.33 \pm 0.11^{\mathrm{a}}$ & $1.26 \pm 0.03^{\mathrm{ab}}$ & $1.18 \pm 0.04^{\mathrm{bc}}$ & $1.08 \pm 0.02^{\mathrm{c}}$ \\
Shank Length & $7.48 \pm 0.02^{\mathrm{b}}$ & $7.55 \pm 0.06^{\mathrm{b}}$ & $6.90 \pm 0.09^{\mathrm{c}}$ & $8.41 \pm 0.12^{\mathrm{a}}$ \\
Thigh Length & $14.06 \pm 0.18^{\mathrm{a}}$ & $14.11 \pm 0.45^{\mathrm{a}}$ & $14.01 \pm 0.67^{\mathrm{a}}$ & $12.47 \pm 0.68^{\mathrm{a}}$ \\
Body Length & $48.12 \pm 0.52^{\mathrm{a}}$ & $45.92 \pm 0.22^{\mathrm{b}}$ & $46.90 \pm 0.79^{\mathrm{ab}}$ & $45.26 \pm 0.12^{\mathrm{b}}$ \\
Neck Length & $14.07 \pm 0.08^{\mathrm{b}}$ & $15.42 \pm 0.18^{\mathrm{a}}$ & $14.89 \pm 0.27^{\mathrm{a}}$ & $13.34 \pm 0.05^{\mathrm{c}}$ \\
Wing Length & $20.54 \pm 0.09^{\mathrm{a}}$ & $20.07 \pm 0.23^{\mathrm{ab}}$ & $19.44 \pm 0.34^{\mathrm{bc}}$ & $18.78 \pm 0.13^{\mathrm{c}}$ \\
Body Circumference & $32.30 \pm 0.33^{\mathrm{a}}$ & $31.61 \pm 0.81^{\mathrm{b}}$ & $30.80 \pm 1.22^{\mathrm{b}}$ & $30.23 \pm 1.02^{\mathrm{b}}$ \\
Wingspan & $44.63 \pm 0.71^{\mathrm{a}}$ & $45.08 \pm 1.7^{\mathrm{a}}$ & $44.20 \pm 2.60^{\mathrm{a}}$ & $39.93 \pm 0.04^{\mathrm{a}}$ \\
Wattle Length & $2.14 \pm 0.02^{\mathrm{a}}$ & $2.32 \pm 0.05^{\mathrm{a}}$ & $2.28 \pm 0.07^{\mathrm{a}}$ & $1.61 \pm 0.01^{\mathrm{b}}$ \\
Helmet Height & $2.22 \pm 0.02^{\mathrm{ab}}$ & $2.27 \pm 0.05^{\mathrm{ab}}$ & $2.33 \pm 0.07^{\mathrm{a}}$ & $2.09 \pm 0.01^{\mathrm{b}}$ \\
\hline
\end{tabular}

Mean \pm Standard error

${ }^{\mathrm{abc}}$ means along the same row with different superscripts are significantly $(\mathrm{P}<0.05)$ different 


\section{Morphometric traits of adult guinea fowl}

Table 2: Means of different morphometric traits for the four varieties of Guinea fowl across four locations

\begin{tabular}{lllllll}
\hline \multicolumn{7}{c}{ Locations } \\
Traits & Saki $( \pm$ SE) & Osogbo $( \pm$ SE $)$ & Ejigbo $( \pm$ SE $)$ & Ogbomoso $( \pm$ SE $)$ & Male $( \pm$ SE $)$ & Female $( \pm$ SE $)$ \\
\hline BW & $1.31 \pm 0.04$ & $1.30 \pm 0.05$ & $1.30 \pm 0.04$ & $1.30 \pm 0.05$ & $1.37 \pm 0.23^{\mathrm{a}}$ & $1.25 \pm 0.22^{\mathrm{b}}$ \\
SL & $7.55 \pm 0.09$ & $7.44 \pm 0.04$ & $7.48 \pm 0.08$ & $7.46 \pm 0.11$ & $7.60 \pm 0.09^{\mathrm{a}}$ & $7.38 \pm 0.047^{\mathrm{b}}$ \\
TL & $14.23 \pm 0.69$ & $14.17 \pm 0.65$ & $13.85 \pm 0.65$ & $13.81 \pm 0.82$ & $14.54 \pm 0.368^{\mathrm{a}}$ & $13.60 \pm 0.51^{\mathrm{b}}$ \\
BL & $46.62 \pm 0.81$ & $46.38 \pm 0.79$ & $45.69 \pm 0.77$ & $46.45 \pm 0.97$ & $46.69 \pm 0.76^{\mathrm{a}}$ & $45.96 \pm 0.43^{\mathrm{b}}$ \\
NL & $14.41 \pm 0.28$ & $14.19 \pm 0.29$ & $14.31 \pm 0.27$ & $14.31 \pm 0.34$ & $14.56 \pm 0.38^{\mathrm{a}}$ & $14.10 \pm 0.15^{\mathrm{b}}$ \\
WL & $20.36 \pm 0.35$ & $20.48 \pm 0.31$ & $20.24 \pm 0.33$ & $20.37 \pm 0.42$ & $20.91 \pm 0.73^{\mathrm{a}}$ & $19.90 \pm 0.187^{\mathrm{b}}$ \\
BC & $31.35 \pm 0.33$ & $32.79 \pm 0.81$ & $32.61 \pm 1.22$ & $31.43 \pm 0.00$ & $32.62 \pm 0.82^{\mathrm{a}}$ & $31.58 \pm 0.67^{\mathrm{b}}$ \\
WS & $44.05 \pm 2.68$ & $43.65 \pm 2.61$ & $46.85 \pm 2.64$ & $43.68 \pm 3.21$ & $47.01 \pm 0.05^{\mathrm{a}}$ & $42.52 \pm 1.43^{\mathrm{b}}$ \\
WaL & $2.18 \pm 0.02$ & $2.13 \pm 0.05$ & $2.18 \pm 0.07$ & $2.14 \pm 0.00$ & $2.63 \pm 0.07^{\mathrm{a}}$ & $1.77 \pm 0.04^{\mathrm{b}}$ \\
HH & $2.22 \pm 0.02$ & $2.22 \pm 0.05$ & $2.26 \pm 0.02$ & $2.23 \pm 0.00$ & $2.52 \pm 0.08^{\mathrm{a}}$ & $1.99 \pm 0.041^{\mathrm{b}}$ \\
\hline
\end{tabular}

BW-Body weight, SL-Shank length, TL-Thigh length, BL-Body length, NL-Neck length, WL-Wing length, BC-Body circumference, WS-Wingspan, WL-Wattle length, HH-Helmet height

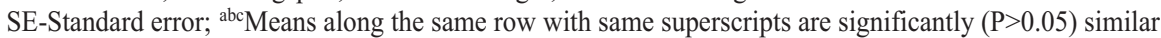

Table 3: Prediction equation for Pearl variety of guinea fowl

\begin{tabular}{clc}
\hline $\begin{array}{c}\text { Optimum } \\
\text { number of } \\
\text { independent } \\
\text { variable }\end{array}$ & \multicolumn{1}{c}{ Regression Equation } & $\mathbf{R}^{\mathbf{2}}$ \\
\hline $\mathbf{1}$ & $\mathrm{BW}=0.99+0.16 \mathrm{WaL}$ & 0.71 \\
$\mathbf{2}$ & $\mathrm{BW}=0.21+0.03 \mathrm{BC}+0.14 \mathrm{WaL}$ & 0.72 \\
$\mathbf{3}$ & $\mathrm{BW}=-0.35+0.04 \mathrm{BL}+0.03 \mathrm{BC}+0.11 \mathrm{WaL}$ & 0.74 \\
$\mathbf{4}$ & $\mathrm{BW}=-0.63+0.01 \mathrm{WS}+0.01 \mathrm{BL}+0.03 \mathrm{BC}+0.11 \mathrm{WaL}$ & 0.75 \\
$\mathbf{5}$ & $\mathrm{BW}=-0.72+0.02 \mathrm{NL}+0.01 \mathrm{WS}+0.01 \mathrm{BL}+0.02 \mathrm{BC}+0.08 \mathrm{WaL}$ & 0.76 \\
$\mathbf{6}$ & $\mathrm{BW}=-0.92+0.03 \mathrm{SL}+0.03 \mathrm{NL}+0.01 \mathrm{WS}+0.01 \mathrm{BL}+0.02 \mathrm{BC}+0.07 \mathrm{WaL}$ & 0.78 \\
$\mathbf{7}$ & $\mathrm{BW}=-0.90+0.03 \mathrm{WL}+0.03 \mathrm{SL}+0.02 \mathrm{NL}+0.01 \mathrm{WS}+0.01 \mathrm{BL}+0.02 \mathrm{BC}+0.07 \mathrm{WaL}$ & 0.79 \\
$\mathbf{8}$ & $\mathrm{BW}=-0.92+0.01 \mathrm{TL}+0.03 \mathrm{WL}+0.03 \mathrm{SL}+0.02 \mathrm{NL}+0.01 \mathrm{WS}+0.01 \mathrm{BL}+0.02 \mathrm{BC}+0.06 \mathrm{WaL}$ & 0.80 \\
$\mathbf{9}$ & $\mathrm{BW}=-0.90+0.02 \mathrm{HH}+0.01 \mathrm{TL}+0.03 \mathrm{WL}+0.03 \mathrm{SL}+0.02 \mathrm{NL}+0.01 \mathrm{WS}+0.01 \mathrm{BL}+0.02 \mathrm{BC}$ & 0.80 \\
\hline
\end{tabular}

$\mathrm{BL}=$ Body length, $\mathrm{BC}=$ Body circumference, $\mathrm{SL}=$ Shank length, $\mathrm{NL}=$ Neck length, $\mathrm{WS}=$ Wingspan, $\mathrm{TL}=\mathrm{Thigh}$

length, $\mathrm{WL}=$ Wing length, $\mathrm{HH}=$ Helmet height, $\mathrm{WaL}=$ Wattle length and $\mathrm{BW}=$ Body weight

Table 4: Prediction equation for Black variety of guinea fowl

\begin{tabular}{clc}
\hline $\begin{array}{c}\text { Optimum } \\
\text { number of } \\
\text { independent } \\
\text { variable }\end{array}$ & \multicolumn{1}{c}{ Regression Equation } & $\mathbf{R}^{2}$ \\
\hline $\mathbf{1}$ & $\mathrm{BW}=-0.10+0.10 \mathrm{WaL}$ & 0.55 \\
$\mathbf{2}$ & $\mathrm{BW}=-0.10+0.06 \mathrm{NL}+0.17 \mathrm{WaL}$ & 0.61 \\
$\mathbf{3}$ & $\mathrm{BW}=0.31-0.03 \mathrm{WL}+0.07 \mathrm{NL}+0.21 \mathrm{WaL}$ & 0.66 \\
$\mathbf{4}$ & $\mathrm{BW}=0.10+0.01 \mathrm{BL}-0.03 \mathrm{WL}+0.06 \mathrm{NL}+0.18 \mathrm{WaL}$ & 0.69 \\
$\mathbf{5}$ & $\mathrm{BW}=-0.32+0.01 \mathrm{WS}+0.01 \mathrm{BL}-0.04 \mathrm{WL}+0.07 \mathrm{NL}+0.15 \mathrm{WaL}$ & 0.71 \\
$\mathbf{6}$ & $\mathrm{BW}=-0.35+0.03 \mathrm{TL}+0.01 \mathrm{WS}+0.01 \mathrm{BL}-0.04 \mathrm{WL}+0.07 \mathrm{NL}+0.15 \mathrm{WaL}$ & 0.72 \\
$\mathbf{7}$ & $\mathrm{BW}=-0.37+0.04 \mathrm{WL}+0.03 \mathrm{TL}+0.01 \mathrm{WS}+0.01 \mathrm{BL}-0.04 \mathrm{WL}+0.07 \mathrm{NL}+0.15 \mathrm{WaL}$ & 0.72 \\
$\mathbf{8}$ & $\mathrm{BW}=-0.46+0.01 \mathrm{BC}+0.04 \mathrm{WL}+0.02 \mathrm{TL}+0.01 \mathrm{WS}+0.01 \mathrm{BL}-0.04 \mathrm{WL}+0.07 \mathrm{NL}+0.15 \mathrm{WaL}$ & 0.73 \\
$\mathbf{9}$ & $\mathrm{BW}=-0.41+0.05 \mathrm{HH}-0.02 \mathrm{SL}+0.01 \mathrm{BC}+0.05 \mathrm{WL}+0.02 \mathrm{TL}+0.01 \mathrm{WS}+0.01 \mathrm{BL}-0.04 \mathrm{WL}+$ & 0.73 \\
\hline
\end{tabular}

$\mathrm{BL}=$ Body length, $\mathrm{BC}=$ Body circumference, $\mathrm{SL}=$ Shank length, $\mathrm{NL}=$ Neck length, $\mathrm{WS}=$ Wingspan, $\mathrm{TL}=\mathrm{Thigh}$

length, $\mathrm{WL}=$ Wing length, $\mathrm{HH}=$ Helmet height, $\mathrm{WaL}=$ Wattle length and $\mathrm{BW}=$ Body weight 


\section{Dudusola, Bashiru and Adewuyi}

Table 5: Prediction equation for Lavender variety of guinea fowl

\begin{tabular}{clr}
\hline $\begin{array}{c}\text { Optimum } \\
\text { number of } \\
\text { independent } \\
\text { variable }\end{array}$ & \multicolumn{1}{c}{ Regression Equation } & $\mathbf{R}^{\mathbf{2}}$ \\
\hline $\mathbf{1}$ & $\mathrm{BW}=0.46+0.31 \mathrm{WaL}$ & 0.49 \\
$\mathbf{2}$ & $\mathrm{BW}=0.01+0.11 \mathrm{WS}+0.30 \mathrm{WaL}$ & 0.58 \\
$\mathbf{3}$ & $\mathrm{BW}=-0.25+0.01 \mathrm{BL}+0.11 \mathrm{WS}+0.18 \mathrm{WaL}$ & 0.63 \\
$\mathbf{4}$ & $\mathrm{BW}=-0.45+0.03 \mathrm{NL}+0.01 \mathrm{BL}+0.11 \mathrm{WS}+0.20 \mathrm{WaL}$ & 0.66 \\
$\mathbf{5}$ & $\mathrm{BW}=-0.40+0.01 \mathrm{WL}-0.03 \mathrm{NL}+0.01 \mathrm{BL}+0.11 \mathrm{WS}+0.20 \mathrm{WaL}$ & 0.68 \\
$\mathbf{6}$ & $\mathrm{BW}=-0.60+0.05 \mathrm{SL}+0.01 \mathrm{WL}-0.03 \mathrm{NL}+0.01 \mathrm{BL}+0.11 \mathrm{WS}+0.20 \mathrm{WaL}$ & 0.71 \\
$\mathbf{7}$ & $\mathrm{BW}=-0.73+0.06 \mathrm{BC}+0.05 \mathrm{SL}+0.01 \mathrm{WL}-0.03 \mathrm{NL}+0.01 \mathrm{BL}+0.11 \mathrm{WS}+0.20 \mathrm{WaL}$ & 0.71 \\
\hline
\end{tabular}

$\mathrm{BL}=$ Body length, $\mathrm{BC}=$ Body circumference, $\mathrm{SL}=$ Shank length, $\mathrm{NL}=$ Neck length, $\mathrm{WS}=$ Wingspan, $\mathrm{TL}=\mathrm{Thigh}$

length, $\mathrm{WL}=$ Wing length, $\mathrm{HH}=$ Helmet height, $\mathrm{WaL}=$ Wattle length and $\mathrm{BW}=$ Body weight

Table 6: Prediction equation for White variety of guinea fowl

\begin{tabular}{clr}
\hline $\begin{array}{c}\text { Optimum } \\
\text { number of } \\
\text { independent } \\
\text { variable }\end{array}$ & \multicolumn{1}{c}{ Regression Equation } & $\mathbf{R}^{\mathbf{2}}$ \\
\hline $\mathbf{1}$ & $\mathrm{BW}=-4.13+0.12 \mathrm{WS}$ & 0.37 \\
$\mathbf{2}$ & $\mathrm{BW}=-4.66+0.08 \mathrm{BC}+0.08 \mathrm{WS}$ & 0.46 \\
$\mathbf{3}$ & $\mathrm{BW}=-5.25-0.12 \mathrm{TL}+0.07 \mathrm{BC}+0.13 \mathrm{WS}$ & 0.50 \\
$\mathbf{4}$ & $\mathrm{BW}=-4.85-0.09 \mathrm{HL}-0.12 \mathrm{TL}+0.08 \mathrm{BC}+0.13 \mathrm{WS}$ & 0.51 \\
$\mathbf{5}$ & $\mathrm{BW}=-3.20+0.16 \mathrm{WL}-0.5 \mathrm{HL}-0.12 \mathrm{TL}+0.08 \mathrm{BC}+0.13 \mathrm{WS}$ & 0.52 \\
$\mathbf{6}$ & $\mathrm{BW}=-4.34+0.03 \mathrm{BL}+0.11 \mathrm{WL}-0.37 \mathrm{HL}-0.12 \mathrm{TL}+0.08 \mathrm{BC}+0.07 \mathrm{WS}$ & 0.54 \\
$\mathbf{7}$ & $\mathrm{BW}=-3.46-0.11 \mathrm{NL}+0.03 \mathrm{BL}+0.11 \mathrm{WL}-0.51 \mathrm{HL}-0.12 \mathrm{TL}+0.08 \mathrm{BC}+0.09 \mathrm{WS}$ & 0.55 \\
$\mathbf{8}$ & $\mathrm{BW}=-4.13+0.05 \mathrm{SL}-0.11 \mathrm{NL}+0.03 \mathrm{BL}+0.11 \mathrm{WL}-0.51 \mathrm{HL}-0.12 \mathrm{TL}+0.08 \mathrm{BC}+0.09 \mathrm{WS}$ & 0.55 \\
$\mathbf{9}$ & $\mathrm{BW}=-3.91+0.05 \mathrm{WaL}+0.05 \mathrm{SL}-0.11 \mathrm{NL}+0.03 \mathrm{BL}+0.11 \mathrm{WL}-0.51 \mathrm{HL}-0.12 \mathrm{TL}+$ & 0.55 \\
\end{tabular}

$\mathrm{BL}=$ Body length, $\mathrm{BC}=\mathrm{Body}$ circumference, $\mathrm{SL}=$ Shank length, $\mathrm{NL}=$ Neck length, $\mathrm{WS}=$ Wingspan, $\mathrm{TL}=\mathrm{Thigh}$

length, $\mathrm{WL}=$ Wing length, $\mathrm{HH}=$ Helmet height, $\mathrm{WaL}=$ Wattle length and $\mathrm{BW}=$ Body weight

\section{Principal component matrix}

Tables 7 and 8 showed the rotated component matrix of the PCA showing the factor solutions for pearl, lavender, black and white varieties of guinea fowl. Following Kaiser Guttman's rule, the principal component with Eigenvalue higher or equal to 1 which accounted for at least $5 \%$ of the variances was retained. Three principal components were yielded by the factor solutions for pearl and black and white; and two principal components for lavender variety.

The result of PCA for the pearl variety shows the first principal component explained $34 \%$ of the total variance in the linear body measurements giving nearly equal emphasis of $(0.36-0.41)$ to thigh length, neck length, wing length, body weight, wattle length, and helmet height. These can be considered as generalized size factors. The second principal component explained $16 \%$ with emphasis on shank length and wing length and the third PC explained only $10 \%$ of the generalized variance.

From the black variety, three (3) principal components were extracted. The first, second and third principal components had Eigen values of $4.43,1.95$ and 1.19, respectively. The three principal components accounted for $75.7 \%$ of the total variance. PC1 had high loadings (correlations between the components and the variables) on thigh length (0.43), wing length (0.41), and body weight (0.38). PC2 loaded heavily on shank length (0.59) and the wingspan (0.47) was orthogonal to PC3 and loaded heavily on body circumference (0.50). From the lavender variety, two (2) principal components were extracted with Eigen values of 4.25 and 2.53 for the first 


\section{Morphometric traits of adult guinea fowl}

and second principal components, respectively. The two principal components accounted for 67.8 percent of the total variance. PC1 had high loadings (correlations between the components and the variables) on thigh length (0.37), body circumference (0.40) and body weight (0.39). PC2 loaded heavily on wing length (0.42) and wingspan (0.47).

According to Pinto et al. (2006), there exists a zero correlation between principal components. Therefore, the principal components obtained could be useful for breeding and selection purposes (Yamaki et al., 2006). As indicated in table 8, PC1 correlated highly with thigh length, body weight and wattle length in pearl, black and lavender varieties which can be termed as the generalized body size. PC2 loaded heavily on shank length and wingspan which can be termed the shank-wing factor. The subsequent component PC 3 was highly correlated with body circumference for pearl variety, neck length and body circumference for black variety, and shank length and body circumference for the white variety.

Table 7: PCA showing the factor solution of pearl and black varieties

\begin{tabular}{lllllll}
\hline & \multicolumn{3}{c}{ Pearl variety } & \multicolumn{3}{c}{ Black variety } \\
Variables & PC1 & PC2 & PC3 & PC1 & PC2 & PC3 \\
\hline Shank length & 0.21 & 0.57 & -0.21 & 0.10 & 0.59 & -0.34 \\
Thigh length & 0.37 & -0.05 & -0.46 & 0.43 & -0.11 & -0.12 \\
Body length & 0.27 & -0.43 & -0.05 & 0.29 & -0.34 & 0.17 \\
Neck length & 0.31 & -0.35 & 0.10 & 0.30 & -0.24 & -0.53 \\
Wing length & 0.24 & 0.40 & -0.22 & 0.33 & 0.31 & -0.33 \\
Body circumference & 0.26 & 0.15 & 0.66 & 0.05 & 0.27 & 0.50 \\
Wingspan & 0.32 & 0.33 & 0.26 & 0.30 & 0.47 & 0.21 \\
Body weight & 0.36 & -0.05 & 0.33 & 0.38 & -0.26 & 0.02 \\
Wattle length & 0.41 & -0.01 & -0.23 & 0.41 & 0.05 & 0.26 \\
Helmet height & 0.36 & -0.27 & -0.10 & 0.35 & -0.06 & 0.30 \\
Eigen value & $\mathbf{3 . 3 7}$ & $\mathbf{1 . 6 5}$ & $\mathbf{1 . 0 0}$ & $\mathbf{4 . 4 3}$ & $\mathbf{1 . 9 5}$ & $\mathbf{1 . 1 9}$ \\
\% of variance & $\mathbf{3 4}$ & $\mathbf{1 6}$ & $\mathbf{1 0}$ & $\mathbf{4 4}$ & $\mathbf{1 9}$ & $\mathbf{1 2}$ \\
\hline
\end{tabular}

$\mathrm{PC}=$ Principal Component.

Table 8: PCA showing the factor solution of lavender and white varieties

\begin{tabular}{llllll}
\hline & \multicolumn{2}{l}{ Lavender variety } & \multicolumn{2}{l}{ White variety } & \\
Variables & PC1 & PC2 & PC1 & PC2 & PC3 \\
\hline Shank length & 0.14 & 0.26 & -0.30 & -0.04 & 0.47 \\
Thigh length & 0.37 & -0.26 & 0.40 & -0.05 & -0.09 \\
Body length & 0.14 & -0.39 & -0.08 & 0.47 & 0.38 \\
Neck length & 0.35 & 0.29 & 0.27 & -0.48 & -0.01 \\
Wing length & 0.32 & 0.42 & 0.43 & 0.17 & -0.17 \\
Body circumference & 0.40 & -0.07 & 0.90 & 0.14 & 0.52 \\
Wingspan & 0.24 & 0.47 & 0.43 & -0.10 & 0.14 \\
Body weight & 0.39 & 0.001 & 0.28 & -0.02 & 0.49 \\
Wattle length & 0.38 & -0.21 & 0.37 & 0.35 & -0.19 \\
Helmet height & 0.30 & 0.43 & -0.02 & 0.60 & 0.20 \\
Eigen value & $\mathbf{4 . 2 5}$ & $\mathbf{2 . 5 3}$ & $\mathbf{4 . 5 7}$ & $\mathbf{2 . 4 0}$ & $\mathbf{1 . 4 6}$ \\
\% of variance & $\mathbf{4 3}$ & $\mathbf{2 5}$ & $\mathbf{4 6}$ & $\mathbf{2 4}$ & $\mathbf{1 5}$ \\
\hline PC Principal Comp & & & & & \\
\hline
\end{tabular}


Dudusola, Bashiru and Adewuyi

Table 9: Summary table for principal components with highest loadings for the four varieties

\begin{tabular}{lllll}
\hline & & \multicolumn{2}{c}{ Variety } & \\
PCs & PEARL & BLACK & LAVENDER & WHITE \\
\hline PC1 & GENERALISED BODY SIZE & GENERALISED BODY & GENERALISED BODY & WING-THIGH \\
& & SIZE & SIZE & FACTOR \\
PC2 & SHANK-WING FACTOR & SHANK-WING FACTOR & WING FACTOR & $\begin{array}{l}\text { NECK-BODY } \\
\end{array}$ \\
& & & & FACTOR \\
PC3 & BODY CIRCUMFERENCE & NECK-BODY FACTOR & & GENERALISED \\
& & & & BODY SIZE \\
\hline
\end{tabular}

Cluster analysis of the morphometric parameters of the four varieties of Guinea fowl

Results from the cluster analysis showed a high similarity index between black and lavender varieties for female birds. The cluster analysis classified the guinea fowl into three main groups based more on sex rather than locations where they were collected nor colour types. The first group consisted of four genotypes which were females from white variety, the varieties in the group were from all the four locations. The second group consisted of nine genotypes which were all males and they are from three varieties (4 male blacks, 4 male pearls and 1 white male). Based on locations, 3 genotypes were from Ejigbo, 2 genotypes were from Saki, 2 genotypes were from Ogbomoso and 2 genotypes were from Osogbo. The third group was the largest and it consisted of a mixture of both

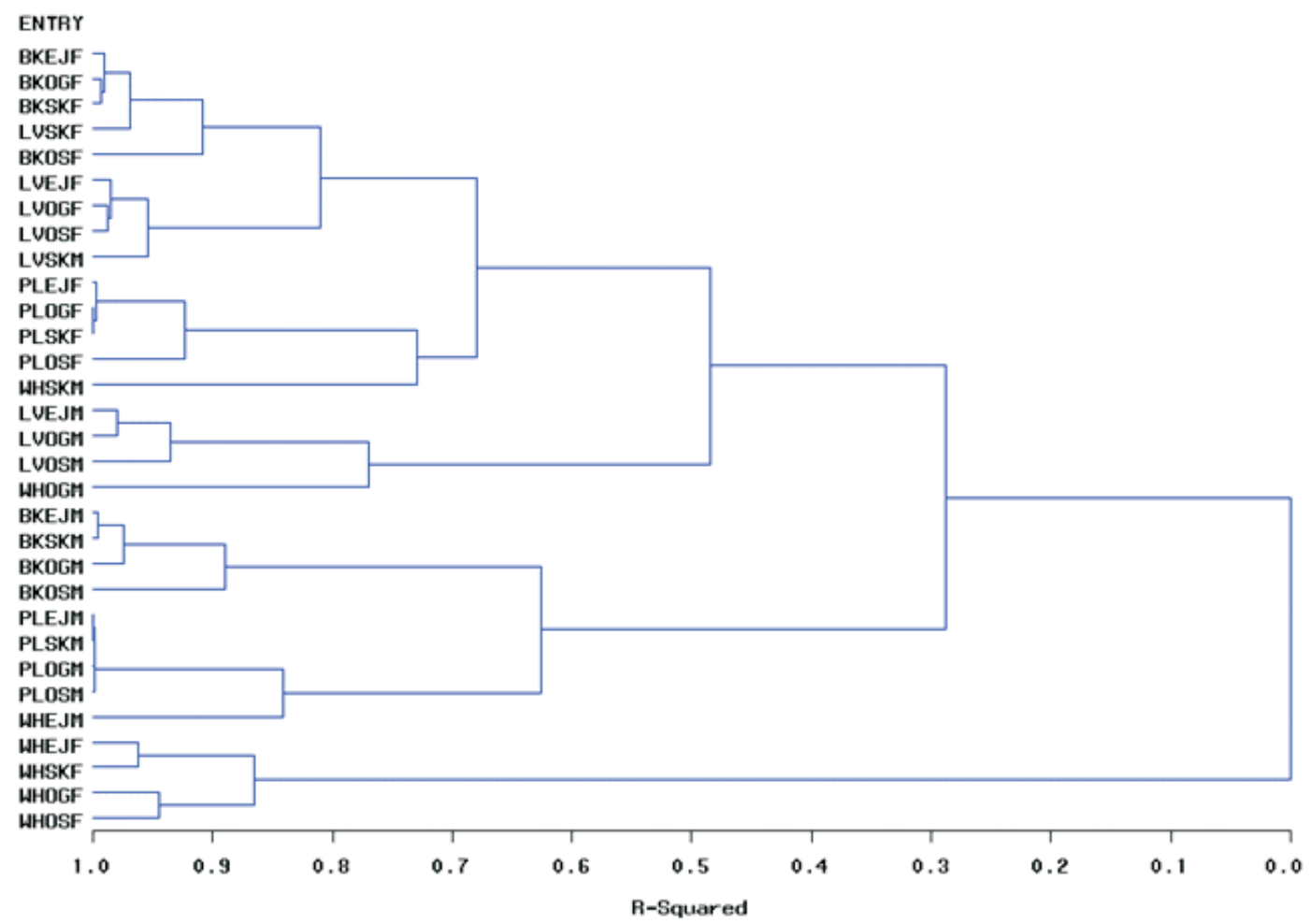




\section{Morphometric traits of adult guinea fowl}

male and female, it has a total of 18 genotypes which were from all the varieties. The number of females in the group was 12 while the male was 6 . The group consisted of 4 black females, 4 lavender females, 4 lavender males, 4 pearl females and 2 white males. Based on location, the group has 4 genotypes from Ejigbo, 5 genotypes from Ogbomoso, 5 genotypes from Saki and 4 genotypes from Osogbo. The implication of this is seen in the production of hybrids. It is expected that a good hybrid can only be produced when there is wide genetic variability in the parents been crossed. The implication in this study is that good hybrids can only be developed from crosses of parents in different groups identified. Although the third group consisted of the largest number of genotypes, both males and females from different locations, it is not advisable to make crosses within the group. A male parent should be crossed with a female parent from a separate group not within the same group.

\section{Conclusion}

Sex had a significant effect on body weight and all body linear measurements of guinea cocks and hens measured. Guinea cocks were significantly higher in body weight and all other body linear traits than their counterpart guinea hens. The study also indicated that body weight can be predicted using body linear parameters. Three principal components were yielded by the factor solutions for pearl and black and white and two principal components for lavender variety. The cluster analysis classified the guinea fowl into three main groups based more on sex rather than locations where they were collected nor colour types

\section{References}

Ayorinde, K. L. and Oluyemi, J. A. 1991. Heritability estimates for body weight in the indigenous pearl guinea fowl in Nigeria. Nigeria. Journal of Genetics, 8: 9-23.

Ayorinde, K. L. 1996. The influence of genetic increase in body weight on conformational and carcass characteristics of pearl guinea fowl. Journal of Animal Science, 60(3): $99-102$

Ayorinde, K. L. 1999. Guinea fowl production systems in Africa. An FAO commissioned report, 24-33.

Ayorinde, K. L. 2004. The spice of life. The $71^{\text {st }}$ Inaugural Lecture, University of Ilorin, Ilorin, Nigeria. 60pp

Baeza, E., Williams, N., Guemene, D. and Duclos, M. J. 2001. Sexual dimorphism for growth in Muscovy duck and changes in insulin-like growth factor I (IGFI), growth hormone (GH) and triiodothyronine (T3) plasma levels. Reproductive Development, 41: 173- 179 .

Chiericato, G. M., Rizzi, C. and Zakaria, H. 2001. Effect of tannin sorghum diet on productive response and meat quality of guinea fowl. Proceedings of the XV European Symposium on the Quality of Poultry Meat. September $9^{\text {th }}-12^{\text {th }}$, Kusadasi-Turkey, pp193-198.

Deeb, N. and Cahaner, A. 2001. Genotype-by-Environment interaction with broiler genotypes differing in growth rate. Poultry Science, 80: 541-548

Dossa, L. H., Wollny, C. and Gauly, M. 2007. Spatial variation in goat populations from Benin as revealed by multivariate analysis of morphological traits. Small Ruminant Research, 73: 150-159.

Fajemilehin S. O. K. 2014. Morphological and genetic characterization of domesticated guinea fowl in 
Sokoto state, Nigeria. Ph.D. thesis, University of Ibadan, Ibadan, p1034

Fajemilehin, S. O. K. and Salako, A. E. 2017. Principal component and cluster analyses of somatometric traits in four varieties of guinea fowls, Numidea meleagris galeata pallas, found in Sokoto State, Nigeria. International Journal of Scientific \& Engineering Research, 8(6): $1736-1743$

Fajuyigbe, O., Balogun V. F. and Obembe O. M. 2007 . Web-based geographical information system (GIS) for tourism in Oyo State, Nigeria. Information Technology Journal, 6:613-622.

Ikani, E. I. and Dafwang, I. I. 2004. The production of guinea fowl in Nigeria. Extension Bulletin No. 207, Poultry Series No. 8. National Agricultural Extension and Research Liaison Services, Zaria, Nigeria.

Johnson, R. A. and Wichern D. W. 2007. Applied multivariate statistical analysis. $6^{\text {th }}$ Edition, Pearson and Education. pp. 671-767.

Kaps, M. and Lamberson, W. R. 2004. Biostatistics for Animal Science. CABI publishing international. pp 282.

Leterrier C., Baeza E., Rebours G., Constantin P., Marche G. and Jemenot, P. 1999. Label production of guinea fowl and carcass quality Proceedings of the XIV European Symposium on the Quality of Poultry Meat. September 19-23, Bologne, 265270.

Mareko M. H. D., Nsoso S. J. and Lebetwa, N. 2008. Nutritive value of meat of guinea fowl raised on concrete and bare soil floors from 16-26 weeks of age. Research
Journal of Animal Science, 2: 5-11.

Mareko M. H. D., Nsoso S. J. and Thibelang, K. 2006. Preliminary carcass and meat characteristics of guinea fowl (Numidia meleagris) raised on concrete and earth floors in Bostwana. Journal of Food Technology, 4: 313-317.

Microlivestock, 1991. Little known small animals with promising economic future. Board on Science and Technology for International Development. Washington, DC: National Academy Press, Washington, pp 115-125.

Pinto, L. F. B., Packer, I. U., De Melo, C. M. R., Ledur, M. C. and Coutinho, L. L. 2006. Principal components analysis applied to performance and carcass traits in the chicken. Animal Research, 55: 419-425.

Porwal, V., Singh B., Kumar D., Sharma R. K. and Pandey, H. 2002. Genetic studies on growth and conformation traits of guinea fowl. Indian Journal of Poultry Science, 37:179-180.

Pudyszak K., Pomianowski J. and Majewska T. 2005. Slaughter value and meat quality of guinea fowl slaughtered at a different age. Food Science and Technology Quality, 42:27-34.

SAS. 2002. SAS Help and documentation. Version 9.0 SAS Institute Inc., Cary, NC. 27513, USA.

Traoré, A., Tamboura, H. H., Kaboré, A., Royo, L. J., Fernandez, I., Avarez, I., Sangaré, M., Bouchel, D., Poivey, J. P., Francois, D., Toguyeni, A., Soawadog, L. and Goyache, F. 2008. Multivariate characterization of morphological traits in Burkina Fasso sheep. Small Ruminant Research, 80: 62-67.

Yakubu, A. and Ibrahim, I. A. 2011. 
Multivariate analysis of morphostructural characteristics in Nigerian indigenous sheep. Italian Journal of Animal Science, 10, 8386.

Yamaki, M., Correa, G. S. S., Silva, M.A., Barbosa, L. and Torres, R. A. 2006. Evaluation of quail carcass traits using principal component analysis. Proceedings of the $8^{\text {th }}$ World Congress on Genetics Applied to Livestock Production, August 13-18, Belo Horizonte, MG, Brazil
Zaky H. I. and Amin, E. M. 2007. Estimates of genetic parameters for body weight and body measurements in Bronze Turkeys (Baladi) by using animal model. Egypt Poultry Science, 27: 151157.

Received: $24^{\text {th }}$ October, 2020

Accepted: $6^{\text {th }}$ February, 2021 